\title{
SLOVO EDITORŮ
}

Jakožto učitelé Ústavu pro dějiny umění Filozofické fakulty Univerzity Karlovy sledujeme pestré aktivity našich studentů a studentek a vážíme si výsledků jejich badatelského úsilí. Domníváme se, že nejlepší z nich stojí za to představit širší veřejnosti a vystavit je tak kritické diskusi, bez níž si rozvoj naší disciplíny nelze dobře představit. Ukázky vědecké činnosti našich žákyň a žáků obsahuje tento svazek univerzitního časopisu Acta. Do jeho první části - Studie - jsme převážně zařadili zajímavé výtažky z dizertací a z magisterských prací obhájených v minulých letech před našimi ústavními komisemi. Některé stati Studií však jejich autoři - studenti doktorského programu Pavla Savická a Tomáš Kolich, ale rovněž naše kolegyně z Ústavu pro dějiny umění FF UK Kateřina Adamcová napsali př́mo pro tento svazek Act. S potěšením konstatujeme, že přes komplikovanou situaci posledního roku se podařilo sestavit obsažný a podle našeho názoru i kvalitní soubor prací.

Př́spěvek Pavly Savické Apuleiův Zlatý osel a antická literární tradice v umění rudolfínské doby prozkoumává klasickými metodami ikonografie a ikonologie ztvárnění proslulého př́běhu o Amorovi a Psyché v dílech dvorních malířu císaře Rudolfa II., Bartholomea Sprangera, Josepha Heintze a Matthäa Gundelacha. Stat významné znalkyně barokního sochařství Kateřiny Adamcové, (Ne)rozluční společníci: Polozapomenuté ikonografické i urbanistické souvislosti vybraných sochařských děl věnovaných sv. Janu Nepomuckému v Praze, rekonstruuje původní kontexty umístění nepomucenských plastik a četbou pramenů z 18. století objasňuje záměry jejich objednavatelů a autorů. Martin Hořák se ve studii „Bildhauer in Stuttgart, sonsten aber aus Prag“: Ondřej Filip Quitainer jako člen družiny pražských umělců $v$ Ludwigsburgu v letech 1709-1714 zaměřil na málo známé práce pražského barokního sochaře pro zámeckou rezidenci vévody Eberharda Ludwiga Württemberského. Česká novobarokní plastika - jiná málo prozkoumaná kapitola $\mathrm{z}$ dějin domácího umění - se stala předmětem zájmu Martiny Bezouškové ve stati Novobaroko a česká sochařská generace devadesátých let 19. století. Tematika dalších příspěvků v oddílu Studia se ocitá na půdě moderní architektury a moderní umělecké tvorby. Problém ochrany funkcionalistických kolonií ve střední Evropě, a to včetně Nového domu v Brně a Baby v Praze, rozebírá Eliška Podholová Varyšová v textu Meziválečné výstavní kolonie Werkbundu v Evropě jako památka. Politickým pozadím př́ípravy masové výstavby prefabrikovaných domů v Československu na přelomu padesátých a šedesátých 
let 20. století se zabývá příspěvek Evy Novotné Panelák jako výsledek vědeckotechnického experimentu. Komparativní studie Ondřeje Hojdy, Japan and Modern Architecture, 1945-1970. Discourse in the mid-20th-century Europe. 1960s: Emancipation, Criticism, rozebírá pohledy euroamerických architektů a publicistů, konkrétně moravského rodáka Bernarda Rudofskyho, na kulturu vzdáleného Japonska. Složitý problém synestetických představ, analyzovaný $\mathrm{v}$ dílech známé české ilustrátorky dětských knih, zaujal Markétu Čejkovou ve stati Synestézie v autorských knihách Daisy Mrázkové. Poslední př́íspěvek v oddílu Studií, Čáry máry: čáry! Nástrahy vizualizací sítí nejen v horizontálních dějinách umění, který napsal Tomáš Kolich, polemizuje s neproblematickým přijímáním pojmů sítě a horizontálních dějin umění v současné uměleckohistorické produkci.

Studentky a studenti Ústavu pro dějiny umění se pravidelně zúčastňují uměleckohistorických i víceoborových konferencí, kolokvií a seminářù a některé z nich sami pořádají. Vedou si též velmi dobře v celostátní soutěži studentů dějin umění Paragone, jejíž poslední ročník v roce 2019 vyhrála absolventka naší katedry Lujza Kotočová. Z několika takových vědeckých setkání jsme se snažili vybrat nejpozoruhodnější př́íspěvky a vyzvali jsme pak jejich autorky a autory, aby je přepracovali do písemné formy pro tato Acta. Především šlo o interdisciplinární konferenci Domov, která v režii studentek a studentů našeho Ústavu proběhla 6. a 7. června 2018 v galerii Tranzitdisplay v Praze. Texty tohoto typu obsahuje druhý oddíl Act, Varia. Skládá se ze statí žákyň a žáků Ústavu pro dějiny umění, ale také z prríspěvků jejich kolegyň a kolegů z jiných institucí, a to v prvním případě i zahraničních.

Text litevské badatelky Karoliny Rybačiauskaité, On Writing Fluid Histories of Modern Art with Jacques Rancière, prozkoumává metodologické možnosti, jaké nabízejí studiu umělecké tvorby v zemích bývalého sovětského bloku podněty pařižského levicového myslitele Rancièra. Úvahy jiného francouzského filozofa, Lévinase, o domově a zabydlování inspirovaly Danielu Matysovou v její stati Emmanuel Lévinas: Domov a umění. Francouzské metodologické kořeny má konečně i př́spěvek medievalistky Jany Kř́žové, Mocenský kalkul jako konstanta i proměnná lidského příběhu v kontextu pojetí královské moci, archetypu a osudu Přemysla Otakara II. v zrcadle školy Annales. Témata domova, soukromí, bezdomoví nebo osvojování cizího se ozvou i v dalších příspěvcích oddílu Varií. Sdělovacími schopnostmi Švabinského podobizny nejpopulárnějšího českého malíre ze sklonku 19. století se zabývá Anežka Mikulcová v textu Domov inspirativní i svazující ve Švabinského portrétu Mikoláše Alše. Na zobrazení domova v pohlednicích z let 1914-1918 a na jejich propagandistický dopad se zaměřil Kamil Beer ve stati Cesta zpátky - domov na pohlednicích 1. světové války. Nad dobovou politikou genderu a nad jejím vyjádřením v dílech Zorky Ságlové, Naděždy Plíškové, Běly Kolářové, Miry Haberernové a Petry Orieškové se zamýšlí text „Soukromé je politické“: Feministické střípky z československého umění šedesátých až osmdesátých let dvacátého století od Marianny Placákové. Barbora Ficková se v Prezentaci německo-českého umění ve stálých expozicích Národní galerie v Praze zaměřila na problém obtížného začleňování děl německojazyčných umělců 20. století do domácího uměleckohistorického kánonu. Vzpomínky lidí připravených v letech 1939-1945 o domov a jejich představy o domově analyzuje antropologický příspěvek Jany Kasíkové Domov a návraty osob přemístěných během druhé světové války (Displaced Persons). Eliška Podholová Varyšová se ve svém druhém textu pro tato Acta, Funkcionalismus - meziválečný fenomén nebo styl přesahující 
válku i sorelu?, zamýšlí nad přežíváním funkcionalistických koncepcí v československé architektuře pozdních padesátých a šedesátých let 20. století. Druhý oddíl Act uzavírá př́spěvek Pološero jako inspirativní hranice (Prolínání undergroundu se současnou městskou baladou), v němž významný představitel českého folku a folkrocku Vladimír Merta vyjasňuje pomocí psychoanalytických a antropologických pojmů vztahy mezi domácí folkovou a undergroundovou hudbou.

Kritériem přijetí všech těchto textů do nového svazku Act pro nás byla atraktivnost jejich tematiky a kvalita zpracování zvolené látky. Stati z oddílů Studie i Varia jsme pak podstoupili recenzentům, kolegům Milanu Pechovi z Katolické teologické fakulty Univerzity Karlovy a z Pedagogické fakulty Jihočeské univerzity a Tomáši Murárovi z Ústavu dějin umění Akademie věd České republiky. Na kritické připomínky obou těchto odborných lektorů reagovali autoři tohoto svazku Act korekcí svých př́íspěvků. Všechny přijaté stati též prošly naší jazykovou a editorskou úpravou. Kromě obou uvedených kolegů bychom rádi poděkovali redakci nakladatelství Karolinum za přijetí tohoto svazku Act k vydání a řediteli Ústavu pro dějiny umění FF UK Richardu Biegelovi za důvěru, jakou do nás vložil jakožto do editorů Act.

Marie Klimešová a Rostislav Švácha 